\title{
Longevity of Nelore Cows of the Bolivian Tropics. Is It Possible to Explain It Through Productive Variables?
}

\author{
Atsuko Ikeda ${ }^{1}$, Ivana Barbona ${ }^{2,3}$, Yoichiro Hayashi ${ }^{5}$, Juan A. Pereira ${ }^{6}$ \& Pablo R. Marini ${ }^{1,2,4}$ \\ ${ }^{1}$ Facultad de Ciencias Veterinarias, Universidad Nacional de Rosario, Argentina \\ ${ }^{2}$ Centro Latinoamericano de Estudios de Problemáticas Lecheras (CLEPL), Argentina \\ ${ }^{3}$ Facultad de Ciencias Agrarias, Universidad Nacional de Rosario, Argentina \\ ${ }^{4}$ Carrera del Investigador Científico (CIC-UNR), Argentina \\ ${ }^{5}$ Cooperativa Agropecuaria Integral San Juan de Yapacaní (CAISY), Bolivia \\ ${ }^{6}$ Universidad Autónoma Gabriel Rene Moreno, Bolivia \\ Correspondence: Atsuko Ikeda, Facultad de Ciencias Veterinarias Universidad Nacional de Rosario, Av. Ovidio \\ Lagos y Ruta 33, S2170HGJ, Casilda, Argentina. Tel: 591-76612126. E-mail: atsukoikedakato@ hotmail.com
}

\author{
Received: July 27, 2019 Accepted: August 16, 2019 Online Published: September 4, 2019 \\ doi:10.5539/sar.v8n4p28 URL: https://doi.org/10.5539/sar.v8n4p28
}

\begin{abstract}
The objective of this work was to evaluate the longevity and its relationship with productive variables of Nelore cows in grazing systems of the Bolivian tropics. Retrospective data were used corresponding to 259 Nelore breed cows, primiparous and multiparous discarded with a total of 800 births, in the period between 2005 and 2019, belonging to the Cooperativa Agropecuaria Integral San Juan de Yapacaní (CAISY) located in the San Juan Japanese Communities, Santa Cruz, Bolivia. The variables analyzed were: Live weight of cow (WC) in $\mathrm{kg}$, Weight of the calf at birth (WCB) in kg, Weight of calf at weaning (WCW) in kg, Total weight of weaned calf (WWC) in kg, Age at first calving (AFC) in months, Number of calvings (NC), Longevity (L) in days, Calf Index (CI) in $\mathrm{kg}$, Accumulated Productivity (PAC) in $\mathrm{kg}$, Total calf production (CP) in $\mathrm{kg}$, Efficiency of Stock (ES) in $\mathrm{kg}$. In order to respond to the main objective of this work, the relationship between the life longevity of the cow and the other productive variables was studied. For this, first principal component analysis (PCA) was carried out, by means of which the space dimension of the productive variables was reduced creating new linearly independent variables and in this way avoid problems of multicollinearity in the model, because the productive variables in some cases turned out to be correlated. Then, the first three main components that explain $77 \%$ of the total variability of the data were retained and interpreted as follows: The PC1 was high and directly correlated with the variables $\mathrm{NC}, \mathrm{Kg}$ produced total, \% of stock efficiency, PAC and $\mathrm{Kg}$ produced meat / day, therefore can be thought of as an indicator of "productive efficiency". PC2 was an indicator of "efficiency in rebreeding" since it presented altar and direct correlations with WC and AFC. PC3 was high and directly correlated with birth weight and weaning weight, which is interpreted as an indicator of "breeding efficiency". Finally, a multiple linear regression model was adjusted considering Longevity as a function of productive efficiency, breeding efficiency and rebreeding efficiency (p-value $<0.0001$ in the three cases). $87 \%$ of the total variability of L (days) is explained by the model. It is concluded that Longevity is related to productive indicators for this group of Nelore cows in grazing systems of the Bolivian tropics.
\end{abstract}

Keywords: cows for meat, aggregate indicators, efficiency, grazing system

\section{Introduction}

In a beef cattle production system, various characteristics affect the economic and productive performance of the herd. The traits that give the greatest impact on beef cattle production systems can be divided into two groups: reproduction and growth. According to Formigoni, Ferraz, Silva, Eler, \& Brumatti, (2005), the reproductive characteristics are of great importance for the definition of objectives of improvement in the production of domestic cattles.

Understanding the factors that affect the biological efficiency of meat cattle of free grazing under uncontrolled environmental conditions is an important step in the search for the identification of optimal genetic types. 
Currently, the major animal evaluation programs are aimed at total production such as body weight gain or calf productions, and slightly pay attention to the necessary supllies to produce cows themselves (Kattnig, Windel, Wallace \& Bailey, 1993).

It is within the framework of this approach, which seeks to take advantage of the grazing systems in which the cow is provided directly with the necessary inputs to meet their food requirements, without the need for transportation, processing or distribution of rations (Molinuevo, 2005). Although it is the most widespread modality, the $\mathrm{kg}$ of weaning calf produced by a cow does not represent the most appropriate indicator to operationalize a complex variable such as productive efficiency and, in this sense, it should be complemented or replaced by other more aggregated indicators that are they constitute alternatives of a more integral measure of production to assess their behavior in grazing systems (Marini \& Di Masso, 2018). Having indicators of this nature would help to avoid the overvaluation of one of the characters involved in the characterization of a good cow for meat over other transcendental ones and would allow to identify the biotypes more adapted to the different environments existing in the place of the evaluation.

For this reason, the objective of this work was to evaluate the relationship of longevity and productive efficiency variables of Nelore cows in grazing systems of the Bolivian tropics.

\section{Materials and Methods}

For the research work, retrospective data corresponding to the period between 2005 and 2019 were used, which belong to the San Juan de Yapacaní Integral Agricultural Cooperative (CAISY) located in the San Juan Japanese Communities, Santa Cruz, Bolivia ( $16^{\circ} 59^{\prime} 0$ "south latitude, $63^{\circ} 58$ ' 0 " west longitude). The place is located at $286 \mathrm{~m}$ above sea level and presents a tropical climate with significant rainfall in most months of the year and a short dry season with little effect on the general climate. The annual average temperature is $24.3^{\circ} \mathrm{C}$ in San Juan Japanese Communities with average rainfall of $1805 \mathrm{~mm}$. The precipitations are minimum in the month of July, with average values of $50 \mathrm{~mm}$. The rainiest month is in January with an average rainfall of $330 \mathrm{~mm}$. The highest average temperatures correspond to the month of January, with values of $26.5^{\circ} \mathrm{C}$ and the lowest to the month of July with records of $20.7^{\circ} \mathrm{C}$

\subsection{Animals}

The data corresponding to 259 cows Nelore breed, primiparous and multiparous discarded with a total of 800 calving were used. The primiparous cows had calving between the months of May and July of each year, while the rest had calving between the months of July and September. Weaning occurs between the seventh and the eighth months in two or three stages depending on the body condition and general condition. Gynecological control is performed routinely, at weaning, by a technical advisor, as well as health controls.

\subsection{Food and Handling}

The feeding of the herd was grazing system in intensive conditions, on 82 hectares with cultivated pastures Brachiaria decumbens (10 to $14 \mathrm{t} / \mathrm{ha} /$ year of DM), Brachiaria humidicola (8 to $12 \mathrm{t} /$ ha / year of DM), Brachiaria dictyoneura (7 at $9 \mathrm{t} / \mathrm{ha} /$ year of DM), Cynodon dactylon (10 to $20 \mathrm{t} / \mathrm{ha} /$ year of DM) and Panicum maximum cv mombaza (20 to $28 \mathrm{t} / \mathrm{ha} /$ year of DM).

\subsection{Reproductive}

The first artificial insemination (AI) was done to the cows in October, then the second AI in early December. In the end of December the natural services were made to cows. To the heifers the first AI were performed in August then the second AI in September, natural services were made in September.

\subsection{Variables to Analyze}

Live weight of cow (WC) in kg: average weight of cow of its life

Weight of the calf at birth (WCB) in kg: average calf weight at birth of all calvings

Weight of calf at weaning (WCW) in kg: Average weight of calf at weaning of all calvings

Total weight of weaned calf (WWC) in $\mathrm{kg}$ : $\Sigma$ of weights at weaning of each cow)

Age at first calving (AFC) in months: Age of first birth (date of birth - date of first calving)

Number of calving (NC): The number of births ( $\Sigma$ of births of each cow)

Longevity (L) in days: Discard date or death - date of birth

Calf Index (CT) in kg: Total production of weaned calf / longevity

Accumulated Productivity (PAC) in kg (Lôbo et al., 2000): 


$$
P A C=\frac{P_{d} * n_{p} * C_{a}}{E V P_{n}-C_{i}}
$$

PAC: $\mathrm{Pd}=$ average weight of weaned calves $(\mathrm{kg}) ; \mathrm{np}=$ total number of calves produced by the cow (born calves); $\mathrm{Ca}=$ constant equal to 365 days that allows expressing fertility on an annual basis; EVPn $=$ age of the cow at the last parturition (days); The characteristics were analyzed using $\mathrm{Ci}=$ constant equal to 550 days approximately 18 months, representing the age at the first conception

Total calf production $(\mathrm{CP})$ in $\mathrm{kg}$ : Total weaning calf weight $*$ Number of births

Stock Efficiency (SE) in kg: Kg produced from calf / Kg maintained from cow

\subsection{Statistic Analysis}

Each of the cows was characterized according to the values of all the variables used. Given that we intend to study the relationship between longevity in days (L) as a function of the other variables, first of all the technique of principal components (PC) was applied to all of them to reduce the dimension of the space of the productive variables and thus avoid problems of multicollinearity by adjusting a longevity model based on these variables. Then, the first three main components that explain $77 \%$ of the total variability of the data were retained and interpreted as follows: The PC1 was high and directly correlated with the variables NC, Kg produced total,\% of stock efficiency, PAC and Kg produced meat / day, therefore can be thought of as an indicator of "productive efficiency". The PC2 was an indicator of "efficiency in rearing" since it presented altar and direct correlations with WC and AFC. PC3 was high and directly correlated with birth weight and weaning weight, which is interpreted as an indicator of "breeding efficiency". A descriptive analysis was carried out identifying the quartiles of the Longevity variable in the biplots graphs made with the three main components, to inspect the possible relationship between Longevity and the three constructed indicators. Finally, a multiple linear regression model was adjusted considering Longevity in terms of productive efficiency, breeding efficiency and rearing efficiency.

\section{Results}

The averages and standard deviations of the variables analyzed were: the length of life $2282 \pm 972$ days, the live weight $490 \pm 55 \mathrm{~kg}$, the age at the first calving $37 \pm 6$ months, the median number of births 2 with a minimum of 1 and a maximum of 11 deliveries, birth weight of $33 \pm 4 \mathrm{~kg}$, weaning weight $203 \pm 35 \mathrm{~kg}$, total calf production $465 \pm 125 \mathrm{~kg}$, stock efficiency $103 \pm 71 \mathrm{~kg}$, cumulative productivity $103 \pm 71 \mathrm{~kg}$ e the calf index $0.202 \pm 0.1 \mathrm{~kg}$.

When carrying out the analysis of main components on the standardized productive variables, the three components were retained:

The equations of the three main components

$$
\begin{array}{ll}
\text { PC1: } & Y_{1}=0.13 X_{1}-0.08 X_{2}+0.41 X_{3}+0.1 X_{4}+0.15 X_{5}+0.46 X_{6}+0.46 X_{7}+0.39 X_{8}+0.45 X_{9} \\
\text { PC2: } & Y_{2}=0.61 X_{1}+0.61 X_{2}+0.19 X_{3}+0.23 X_{4}-0.19 X_{5}+0.12 X_{6}+0.03 X_{7}-0.31 X_{8}-0.12 X_{9} \\
\text { PC3: } & Y_{2}=-0.08 X_{1}+0.28 X_{2}-0.26 X_{3}+0.57 X_{4}+0.69 X_{5}-0.12 X_{6}-0.1 X_{7}+0.16 X_{8}+0.04 X_{9}
\end{array}
$$

The first component (PC1) explained $49 \%$ of the total variability observed. The strongest association, judging by the values of the correlations of the original variables and the PC1, in this case, were with calving number, total calf production, stock efficiency, cumulative productivity and calf index. Consequently, the first component could be called "PRODUCTION". The higher the value of PC1, the greater the longevity.

The second component (PC2) explained 16\% of the total variability observed. When observing the correlations between the original variables and the PC, the strongest association was with the age of the first birth and the live weight. Consequently, the component could be called "EFFICIENCY IN THE RECRIA". The higher the value of $\mathrm{PC} 2$, the greater the longevity

The third major component (PC3) explained $12 \%$ of the observed variance. In this case, the variables weight at birth and weight at weaning were the most correlated with PC3. Consequently, the third component could be called "EFFICIENCY IN THE BREEDING". The higher the value of PC3, the greater the longevity. 
Table 1. Correlations with the original variables

\begin{tabular}{llll}
\hline Variables & PC 1 & PC 2 & PC 3 \\
\hline Weight of cow in kg & 0.27 & 0.73 & -0.08 \\
Age of first calving (months) & -0.18 & 0.73 & 0.29 \\
Number of calvings & 0.87 & 0.23 & -0.27 \\
Weight of the calf at birth (kg) & 0.22 & 0.28 & 0.59 \\
Weight of weaning calf $(\mathrm{kg})$ & 0.31 & -0.23 & 0.71 \\
Total calf production (kg) & 0.97 & 0.15 & -0.12 \\
\% Stock Efficiency & 0.96 & 0.04 & -0.11 \\
PAC (kg) & 0.82 & -0.37 & 0.17 \\
Kg production of meat/day & 0.95 & -0.14 & 0.05 \\
\hline
\end{tabular}

Note. $\mathrm{PC} 1=$ first component, $\overline{\mathrm{PC} 2}=$ second component, $\mathrm{PC} 3=$ third component, $\mathrm{PAC}=$ accumulated productivity

As an exploratory analysis, longevity (L) was classified according to their quartiles and these were identified in the biplots graphs (Figure 1, Figure 2 and Figure 3) for the three components. It was observed that the values of the variable L increased, as the productive efficiency increased (PC1). However, it was not observed directly, by means of these graphs, if there could be some kind of relationship between the quartiles of longevity and the efficiency in rearing $(\mathrm{PC} 2)$ and breeding $(\mathrm{PC} 3)$.

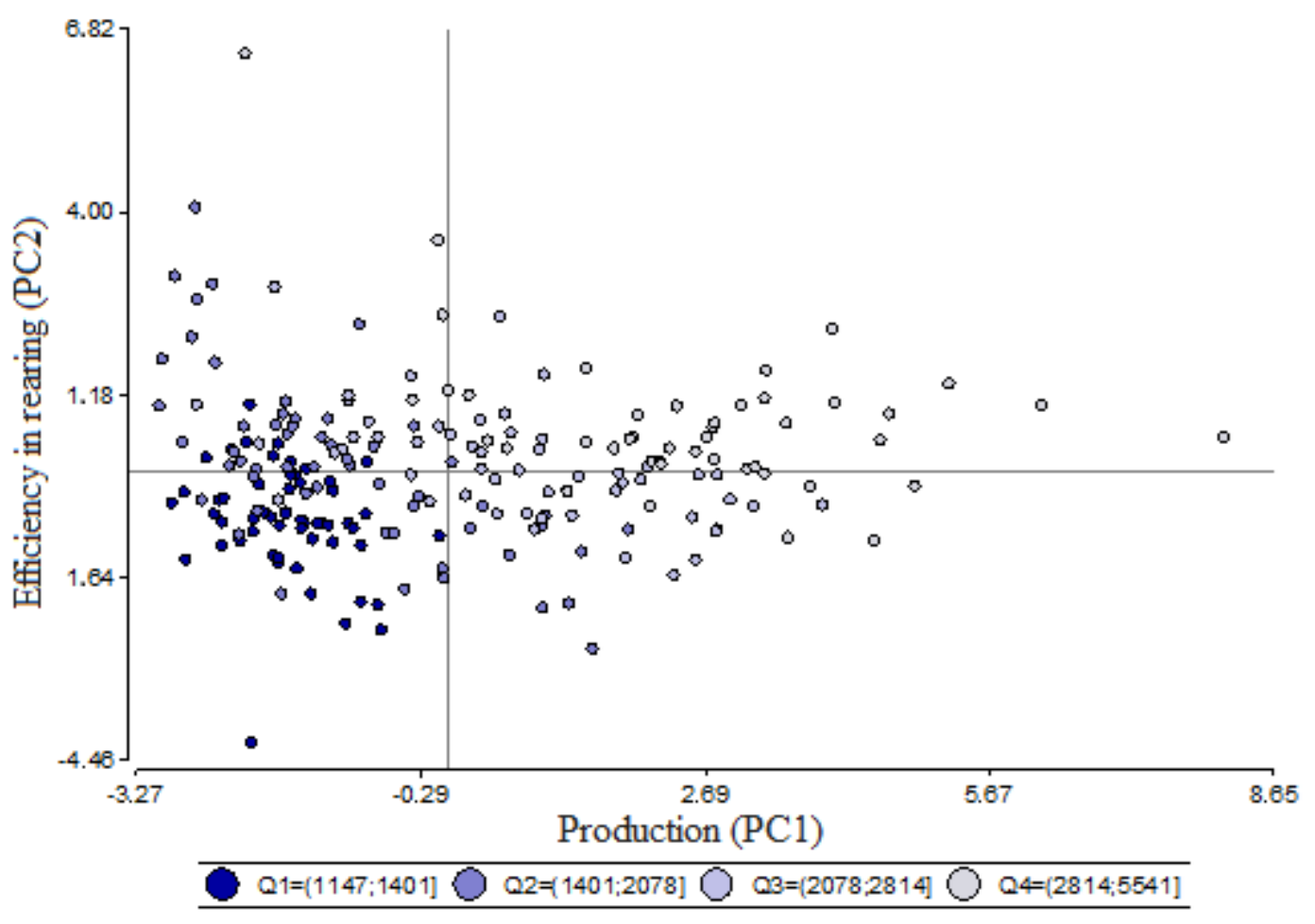

Figure 1. Production (PC1) vs efficiency in rearing (PC2) 


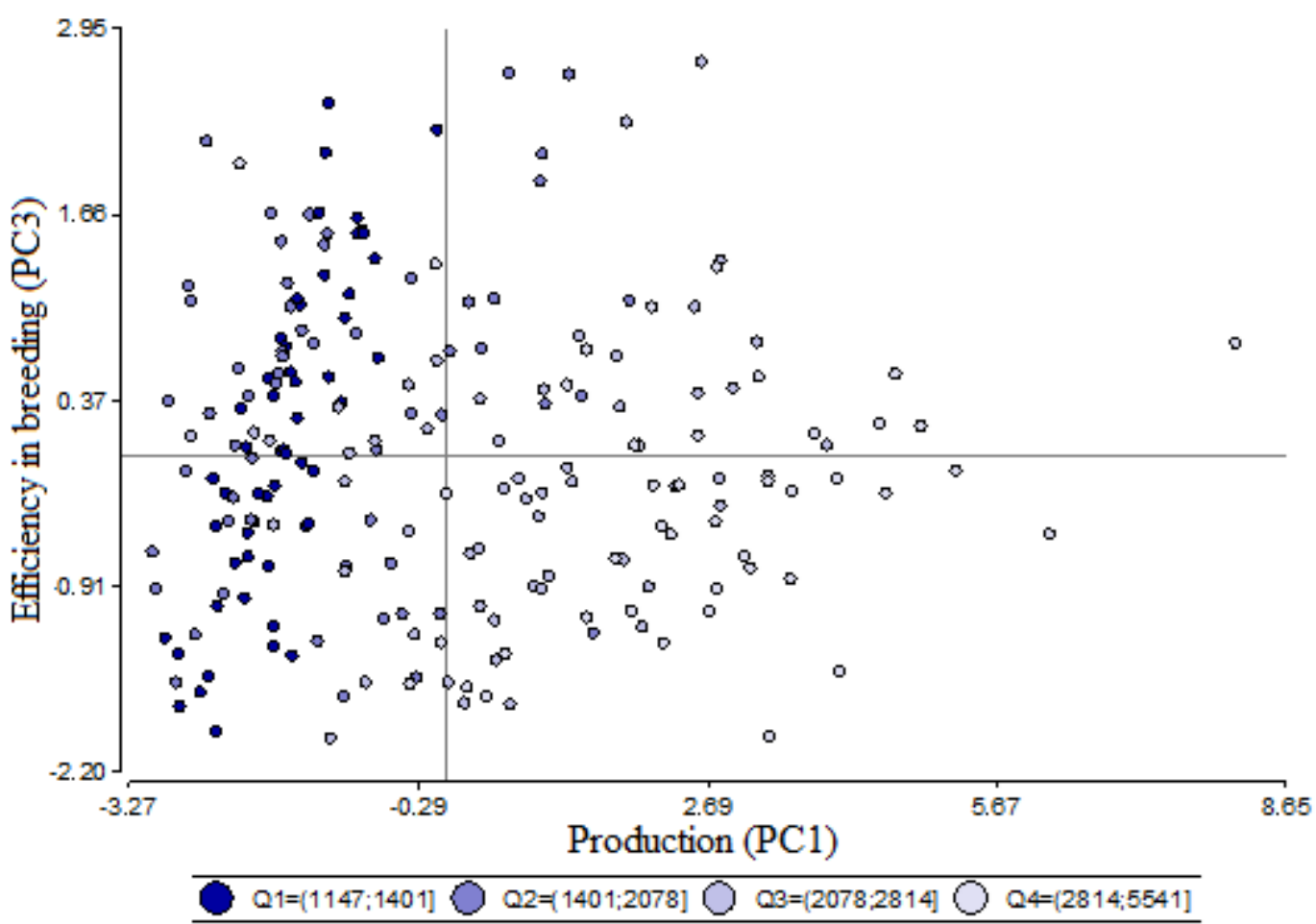

Figure 2. Production (PC1) vs efficiency in breeding (PC3)

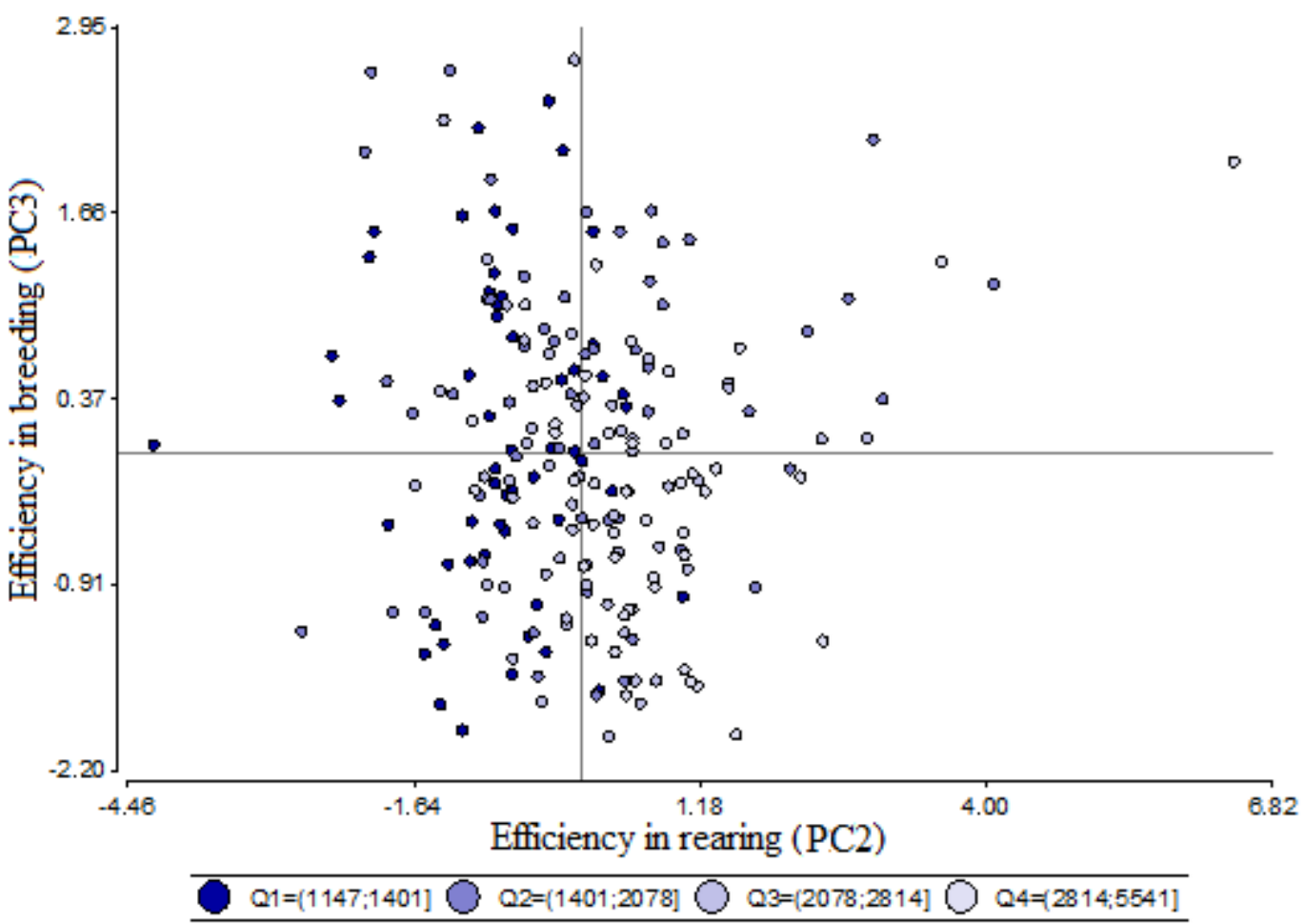

Figure 3. Efficiency in rearing (PC2) vs efficiency in breeding (PC3) 
Subsequently, a multiple linear regression model of Longevity was adjusted according to the productive efficiency (PC1), efficiency in rearing (PC2) and efficiency in breeding (PC3), in order to study the possible relationship between these three variables at the same time and longevity. It was observed that there is a significant linear relationship in the three cases (p-value $<0.0001$ in each explanatory variable). $87 \%$ of the total variability of L (days) is explained by the model. When interpreting the regression coefficients, for each unit increase in the productive efficiency, leaving the values of efficiency in breeding and rearing fixed, the average longevity increases 334.9 days (p-value $<0.0001$ ). In the case of the efficiency in the rearing, for each unitary increase in this variable leaving fixed the values of productive efficiency and in the young, the longevity increases in average 298.7 days ( $p$-value $<0.0001$ ).

For each unitary increase in the efficiency in the breeding, leaving fixed the values of productive efficiency and in the rearing, the longevity decreases in average 193.30 days (p-value <0.0001). Compliance with the assumptions of the model was checked and verified through graphic and inferential procedures.

\section{Discussion}

The overall productivity of a cow will depend on its behavior during its life, which is influenced by several factors: the length of stay of the cow in the establishment, the number of lactations completed, the number of calving, milk production, duration of accumulated lactations, among others. Once the genetic constitution is defined, the productive behavior in general will be subject to environmental changes, management and other non-genetic factors (Chirinos, González-Stagnaro, Madridbury, \& Rivera, 1999, Khushik, Agarwai, \& Garg, 1994). Reproductive performance is one of the most important factors affecting the efficiency of meat cow production and it has been estimated that reproduction is three to nine times more influential in profitability than other production traits (Melton, 1995). Compared with other animal species of meat production, the long production cycle and the low reproduction rate of livestock require a higher level of energy inputs used by each cow (Dickerson, 1978). The results found in this work with respect to the variables analyzed separately are similar to other works, Foianini, Pereira, Landivar, \& Ortiz (2010), Lopes, Silva, Marques, \& McManus (2011) Malhado et al. (2009), Duitama, González, García, Farah, \& Da Fonseca (2013), Segura-Correa, Magañ Monforte, \& Centurión-Castro (2013), Rosa (1999), Ikeda \& Marini (2018). The joint consideration of these variables would indicate that, on average, these cows have their first birth at three years, have a life of six years with two births and a low productive efficiency evaluated with indicators of biological efficiency. The lack of information on aggregate efficiency indicators in cow-breeding systems represents a limitation for the evaluation of both genotypes or racial groups and the impact of other non-genetic management strategies on the biological and economic efficiency of the systems. Much of the efforts to improve livestock efficiency have focused on different measures of feed efficiency (variations in amount of feed consumed and weight gain rate) determined during the growth phase. While this approach provides relevant information on efficiency during the growth phase, the relationship with the efficiency of cows has yet to be determined. In cows, the most critical factor that influences efficiency performance is the reproductive lifetime rate, not the weight gain (Roberts, Funston, Mulliniks, Petersen, \& MacNeil, 2011). Although the consideration of each variable separately is relevant as reference values are available that allow these cows to be positioned in particular in the concert of the production of meat of the Nelore breed, the characterization of the efficiency of the productive system requires the joint analysis of all of them rather than their individual consideration. The three components generated in the multivariate analysis can be considered new random variables that, because they are not correlated with each other, explain independent portions of the total variance observed in the population, being of interest to mark that the three components are linked in a positive way, showing that the increase of each one of them allows a greater longevity.

\section{Conclusions}

It is concluded that there is a relationship between the longevity and productive efficiency variables of Nelore cows in grazing systems of the Bolivian tropics.

\section{References}

Chirinos, Z., González-Stagnaro, C., Madridbury, N., \& Rivera, J. (1999, November 1). Vida útil, longevidad y causas de eliminación en vacas mestizas de doble propósito. Revista Científica. FCV-LUZ. IX(6), 477-484. Retrieved from https://produccioncientificaluz.org/index.php/cientifica/article/view/14548

Dickerson, G. E. (1978). Animal size and efficiency: basic concepts. Animal Production, 27, 367-379. https://doi.org/10.1017/S0003356100036278

Duitama, O. C., González, L. H., García, D., Farah, M., \& Da Fonseca, R. (2013, October 15). Productividad 
acumulada y su relación genética con características reproductivas en hembras Brahman. Revista MVZ Córdoba, 18(Supl), 3658-3664. https://doi.org/10.21897/rmvz.132

Foianini, J. C. S., Pereira, J. A., Landivar, J. H., \& Ortiz, J. (2010). Determinación del período de gestación de terneros Nelore nacidos de I.A. y T.E. Tesis de grado FMVZ - UAGRM Santa Cruz - Bolivia pp. 70.

Formigoni, I. B., Ferraz, J. B. S., Silva, J. A. I. I. V., Eler, J. P., \& Brumatti, R. C. (2005). Valores econômicos para habilidade de permanência e probabilidade de prenhez aos 14 mees em bovinos de corte. Arquivo Brasileiro de Medicina Veterinária e Zootecnia, 57, 220-226. https://doi.org/10.1590/S0102-09352005000800013

Ikeda, A., \& Marini, P. R. (2018). The behaviour of nelore cows of different ages as an indicator of efficiency in a pasturing system in the bolivian tropic. 30th World Buiatrics Congress, Sapporo, Japón. Retrieved from https://confit.atlas.jp/guide/event/wbc2018/sessions/classlist/1022

Kattnig, R. M., Windel, J. A., Wallace, J. D., \& Bailey, C. C. (1993, October 10). Evaluation of Biological Efficiency of Free-Grazing Beef Cows Under Semidesert Conditions, Journal of Animal Science, 71, 2601-2607. https://doi.org/10.2527/1993.71102601x

Khushik, S. N., Agarwai, S. C., \& Garg, R. C. (1994). Lifetime traits in Hariana cattle. Indian Journal of Animal Science, 64, 1104-1107.

Lopes, F. B., Silva, M. C., Marques, E. G., \& McManus, C. (2011, July/September). Ajustes de curvas de crescimento em bovinos Nelore da região Norte do Brasil. Revista Brasileira de Saúde e Produção Animal, 2, 607-617. http://mc04.manuscriptcentral.com/rbspa-scielo

Malhado, C. H. M., Ramos, A. A., Carneiro, P. L. S., Azevedo, D. M. M. R., Melo, P. R. A. R., Pereira, D. G., Souza, J. L., \& Martins, F. R. (2009). Modelos não lineares utilizados para descrever o crescimento de bovinos da raça Nelore no estado da Bahia: 1. Efeito ambiental. Revista Brasileira de Saúde e Produção Animal, 10, 821-829. https://mc04.manuscriptcentral.com/rbspa-scielo

Marini, P. R., \& Di Masso, R. J. (2018 September / February). Evaluación histórica de indicadores productivos en vacas lecheras en sistemas a pastoreo. Revista de Ciencias de la Vida, 28(2), 103-115. http://dx.doi.org/10.17163/lgr.n28.2018.08

Melton, B. E. (1995). Conception to Consumption: The Economics of Genetic Improvement. In: Proceedings of the Beef. Improvement Federation, 27, Research Symposium and Annual Meeting, Sheridan, pp. 40-47

Molinuevo, H. A. (2005). Selección de bovinos lecheros para el sistema en pastoreo. In: H. A. Molinuevo (Ed.), Genética bovina y producción en pastoreo (pp. 283-315). INTA, Argentina.

Roberts, A., Funston, R., Mulliniks, T., Petersen, M., \& MacNeil, M. (2011). Feed efficiency - how should it be used for the cow herd?. Range Beef Cow Symposium. Paper 281. Retrieved from http://digitalcommons.unl.edu/rangebeefcowsymp/281

Rosa, A. N. (1999). Variabilidade fenotípica e genética do peso adulto e da Produtividade acumulada de matrizes em rebanhos de seleção da raça Nelore no Brasil Ribeirão Preto: Universidade de São Paulo. pp. 114. (Unpublished doctoral dissertation) Universidade de São Paulo.

Segura-Correa, J. C., Magañ Monforte, J. G., \& Centurión-Castro, F. (2013). Efecto de grupo racial y edad al primer parto sobre el número de partos durante la vida útil de vacas cebú. Archivos de Medica Veterinaria, 41-44. http://dx.doi.org/10.4067/S0301-732X2013000100007

\section{Copyrights}

Copyright for this article is retained by the author(s), with first publication rights granted to the journal.

This is an open-access article distributed under the terms and conditions of the Creative Commons Attribution license (http://creativecommons.org/licenses/by/3.0/). 